\title{
Hasfali endometriosis: differenciáldiagnosztikai nehézségek a radiológus szemszögéből
}

\author{
Csorba Csenge dr. ${ }^{1,2}$ - Pásztor Norbert dr. $^{3}$ - Szalma Emese oh. ${ }^{2}$ \\ Kovács Gabriella dr. ${ }^{1}$ - Palkó András dr. ${ }^{2}$ - Fejes Zsuzsanna dr. ${ }^{1,2}$
}

\author{
${ }^{1}$ Affidea Magyarország Kft., Nyugati Telephely, Szeged \\ ${ }^{2}$ Szegedi Tudományegyetem, Általános Orvostudományi Kar, Radiológiai Klinika, Szeged \\ ${ }^{3}$ Szegedi Tudományegyetem, Általános Orvostudományi Kar, Szülészeti és Nőgyógyászati Klinika, Szeged
}

\begin{abstract}
Az endometriosissal küzdő betegek száma, ezen belül az atípusos megjelenési formák előfordulása is folyamatosan növekszik, ez pedig a képalkotó diagnosztát is növekvő kihívás és fejlődés elé allíitja. Retrospektív módon a 2016 és 2018 közötti, női páciensek esetében végzett ultrahangvezérelt intervenciós vizsgálatokat tekintettük át, melyek ismeretlen dignitású hasfali terime miatt történtek a Szegedi Tudományegyetemmel együttmúködő diagnosztikai központjainkban. A hasfali eltérések közül egyet CT-, a többit ultrahangvizsgálat során észleltük mellékleletként. Összesen 12 eset felelt meg a beválogatási feltételeknek. A betegek átlagéletkora 59 év (29-79 év), az eltérések átlagos mérete 34,4 mm (20-49 mm) volt; az anamnézisben hasfali mútét 8 esetben szerepelt. A kivizsgálás indikációja minden esetben malignus folyamat vagy annak gyanúja volt, a mintavételt 4 esetben MRI-vizsgálat előzte meg. Ezeken kívül további 2 esetben a hasfali képlet excízióját nem előzte meg ultrahangvezérelt mintavétel, az endometriosis diagnózisát az eltávolított képlet patológiai vizsgálatával állítottuk fel. Egy esetben a szövettani diagnózis primer, serosus típusú epithelialis malignus tumort, hat esetben metasztázist, hat esetben endometriosist, egy esetben pedig hasfali tályogot igazolt. Az endometriosis a fiatalabb korosztályban fordult elő. Fiatal, praemenopausában lévő nóbetegek hasfali képletének eseteiben az endometriosis valószínúsége kifejezetten nagy, fóként, ha az anamnézisben szülészeti vagy nőgyógyászati mútét is szerepel. Az elváltozás felismerésében, illetve a későbbi sebészi kezelés megtervezésében az ultrahangvizsgálatnak elsődleges szerepe van.
\end{abstract}

Orv Hetil. 2019; 160(35): 1395-1402.

Kulcsszavak: hasfali endometriosis, transabdominalis ultrahangvizsgálat, ultrahangvezérelt mintavétel

\section{Differential diagnostic challenges of abdominal wall endometriosis from the radiologist's point of view}

The incidence of endometriosis, including atypical forms of the disease, has been continuously growing, thus increasingly challenging for the imaging specialists as well. We conducted a retrospective study to analyze the results of ultrasound-guided interventions between 2016 and 2018. All interventions were performed in female patients due to uncertain abdominal wall lesions at the University of Szeged, Hungary. The abdominal wall lesions were incidentally detected, one by CT, the others by ultrasound examinations. We identified 12 cases during the study period. The average age of the patients was 59 years (29-79), 8 of them had abdominal surgery in their medical history. The mean diameter of the masses was $34.4 \mathrm{~mm}(20-49 \mathrm{~mm})$. Since the indication of imaging examinations was the evaluation of a known or suspected malignancy, four patients had undergone an MRI prior to the biopsy. In addition, ultrasound-guided biopsy was not performed in another two patients, and the diagnosis was established by histological examination of the surgically removed specimens. The histological examination revealed malignant primary serous epithelial tumor in one case, metastases in six cases, endometriosis in six patients and abdominal wall abscess was found in one patient. Endometriosis was more frequent in the younger patients. The likelihood of endometriosis as a cause of abdominal wall lesions of younger, premenopausal female patients is rather high, especially with obstetrical or gynaecological operations in the medical history. Ultrasound plays a primary role in the detection and therapy planning of these lesions.

Keywords: abdominal wall endometriosis, transabdominal ultrasonography, ultrasound-guided biopsy

Csorba Cs, Pásztor N, Szalma E, Kovács G, Palkó A, Fejes Zs. [Differential diagnostic challenges of abdominal wall endometriosis from the radiologist's point of view]. Orv Hetil. 2019; 160(35): 1395-1403.

(Beérkezett: 2019. február 26.; elfogadva: 2019. április 3.) 


\section{Rövidítések}

ALARA $=($ as low as reasonably achievable $)$ a sugárterhelésnek az észszerúen elérhető legalacsonyabb sugárzási szinten tartása; $\mathrm{CT}=$ (computed tomography) számítógépes tomográfia; MRI = (magnetic resonance imaging) mágnesesrezonanciaképalkotás

Európai felmérések szerint az endometriosis a fogamzóképes korú nők 10-15\%-át érinti [1]. Évente 7,2 új eset jut 10000 nőre, a frissen diagnosztizált betegek a leggyakrabban 25-39 év közöttiek [2]. Több rizikófaktort azonosítottak, amelyek az endometriosis kialakulásához vezethetnek. A korai menarche, illetve a rövidebb menstruációs ciklus, a nagyobb testmagasság, a jelentôs alkohol- és koffeinbevitel mind kockázati tényezők az endometriosis kialakulásában. Bizonyos állapotok, faktorok azonban csökkentik a betegség kialakulásának valószínűségét, például a szülés vagy a rendszeres fizikai aktivitás és az ómega- 3 zsírsavakban gazdag étrend. A többszörösen telítetlen zsírsavak egyes gyulladásos faktorok szintjének csökkentésén keresztül hatnak, míg a fizikai aktivitás védőhatására még nem találtak magyarázatot. A dohányzás - vélhetően az ösztrogénszintet csökkentô hatása miatt - az endometriosis kialakulásának veszélyét is csökkenti [3].

Hasfali endometriosisról akkor beszélünk, amikor az endometrialis mirigy- és stromaállomány a bőrben, a bőr alatti kötőszövetben vagy a has- és kismedencei izomzatban helyezkedik el. Összességében elmondhatjuk, hogy előfordulási gyakorisága ritka, az összes endometriosis kb. 2\%-a. Hasfali endometriosisok a leggyakrabban a császármetszések hegében fordulnak elő, megközelítőleg 0,03-0,4\%-os gyakorisággal. Fontos megemlíteni, hogy napjainkban a császármetszések indikációs köre szélesebb, ezáltal a császármetszések aránya emelkedik, így vele párhuzamosan a hasfali endometriomák előfordulási gyakorisága is folyamatosan növekvő tendenciát mutat. Egy korábbi felmérés szerint hasfali endometriosisban szenvedő betegek kórelőzményét vizsgálva, 82,3\%-ban császármetszés, 11,7\%-ban gátmetszés, illetve 5,8\%-ban az endometrialis petefészekciszta laparoszkópos módszerrel történő eltávolítása szerepel $[4,5]$. Prediszponáló tényező lehet még a transabdominalis amniocentesis. Habár a legtöbbször az anamnézisben nőgyógyászati intervenció szerepel, az irodalomban találunk példát nem nőgyógyászati mútétet követô hegendometriomára, így appendectomia vagy köldöksérvmútét hegében kialakult endometriomára is, sőt leírtak hasfali endometriosist olyan páciens esetében is, akinek a kórelőzményében mútét nem szerepelt.

Patomechanizmusára a legszélesebb körben elfogadott elmélet az implantációs teória. E szerint nőgyógyászati vagy más nyitott hasfali műtét során az endometrialis sejtek szétszóródnak a hasfal rétegei között [6].

Célkitűzésünk volt saját beteganyagunkban elemezni azon női páciensek adatait, akiknél ismeretlen dignitású, képalkotó vizsgálat során mellékleletként talált hasfali képlet miatt ultrahangvezérelt mintavétel vagy mútét történt. A csoporton belül kiemeltük és elemeztük az endometriosis szövettanával rendelkező betegeket, hogy feltárjuk és felhívjuk a figyelmet a hasfali endometriosis differenciáldiagnosztikai nehézségeire.

\section{Minta és módszer}

Vizsgálatunk során retrospektív módon áttekintettük a 2016 és 2018 közötti időszakban végzett ultrahangvezérelt szövettani mintavételek és intervenciók adatait. Az analízisbe azokat a nói betegeket válogattuk be, akiknél a hasfal rétegeiben (a bőrben, a bőr alatti kötőszövetben vagy a has- és kismedencei izomzatban) a rutin képalkotó vizsgálat bizonytalan dignitású terimét igazolt. Elemzésünkből kizártuk azokat a betegeket, akiknél a szövettani mintavétel a hasüregból történt. Ezenfelül a jelen összefoglalóba 2 olyan esetet is bevontunk, amelynél ultrahangvezérelt mintavételt nem végeztünk ugyan, viszont a képalkotó diagnosztikai lépések után a hasfali képlet sebészi eltávolítása megtörtént, így szövettani diagnózis a rendelkezésünkre állt.

Az ultrahangvizsgálatok és az ultrahangvezérelt mintavétel LOGIQ S8 készülékkel (General Electric, Cleveland, $\mathrm{OH}$, Amerikai Egyesült Államok) történt. A CTvizsgálatok Brilliance iCT (Philips, Amszterdam, Hollandia), az MRI-vizsgálatok pedig Signa Excite HDxT 1,5 T készülékkel (General Electric) készültek.

\section{Eredmények}

A vizsgált időszakban összesen 517 ultrahangvezérelt mintavételt végeztünk, melyből 12 esetben $(2,3 \%)$ történt ultrahangvezérelt biopszia a hasfal rétegei között elhelyezkedő ismeretlen képletból. Ezeken kívül 2 esetben a képalkotó vizsgálatot nem követte mintavétel, szövettani diagnózist a sebészeti úton eltávolított képlet patológiai feldolgozása adta.

A betegek átlagéletkora 59 év volt, a legfiatalabb beteg 29 éves, a legidősebb pedig 79 éves volt. Hasi mútéti beavatkozás, így császármetszés $6(42,8 \%)$ esetben, az inguinalis régióban sérvmútét $1(7,2 \%)$ esetben, epehólyagmútét, illetve stomakihelyezés további 1-1 (7,2$7,2 \%)$ beteg esetében szerepelt az anamnézisben. A 14 esetből $13(92,8 \%)$ páciensnél a hasfali elváltozás rutinultrahangvizsgálat során került felfedezésre, ahol 9 alkalommal azt rögtön mintavétel követte. Egy esetben $(7,2 \%)$ CT-vel mellékleletként észleltük a hasfali terimét. Főként a fiatalabb korosztály esetében a biopszia előtt kiegészítő MRI-vizsgálat történt $4(28,6 \%)$ esetben, az eltérés esetleges pontosabb karakterizálásának céljából. A vizsgált terimék legnagyobb átméróje átlagosan 34,4 $\mathrm{mm}(20-49 \mathrm{~mm})$ volt.

$6(42,8 \%)$ esetben a mintavétel metasztázist igazolt, ezekben az esetekben a tumoros alapbetegség ismert volt. A betegek gyomor-, illetve colorectalis eredetú ade- 


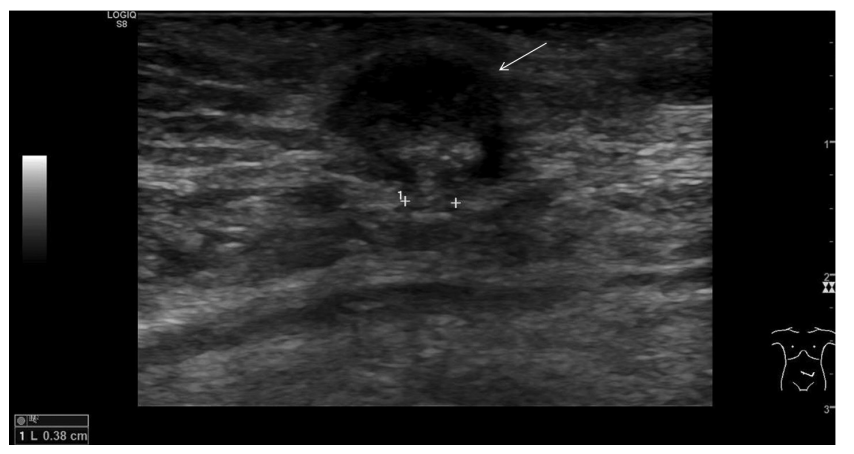

l. ábra $\quad$ A 31 éves beteg ultrahangvizsgálata során (lineáris fej, 8,5 $\mathrm{MHz}) 13 \mathrm{~mm}$ legnagyobb átmérőjü, kizáródóban lévő, echószegény tartalommal kitöltött köldöksérvnek tartott eltérés azonosítható (nyíl)

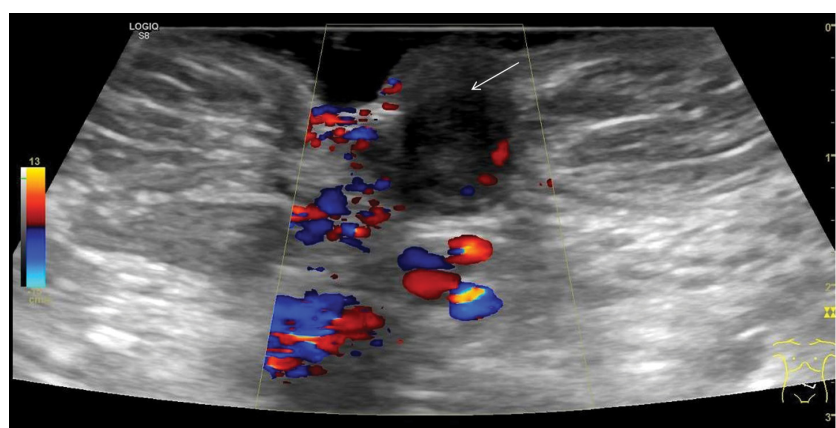

2. ábra

A sérvtömlőnek tartott eltérésről készített felvételen (lineáris fej, 8,5 MHz) color-Doppler-vizsgálattal, érzékeny paraméterek mellett jó keringést sikerült kimutatni (nyíl). A kizáródott köldöksérv miatt mútétet végeztek, az operációt követő szövettan feldolgozás endometriosist igazolt

nocarcinomában, ovariumcarcinomában és melanoma malignumban szenvedtek. A betegek postmenopausában voltak, a metasztázis diagnózisa valószínü volt a klinikumot áttekintve már a mintavétel előtt. Egy esetben serosus típusú epithelialis tumor került leírásra, valamint egy esetben tályog igazolódott, mely utóbbi a klinikum alapján szintén feltételezhető volt.
Az elvégzett szövettani vizsgálat hasfali endometriosist igazolt $6(42,8 \%)$ esetben. Ezen páciensek mind praemenopausában voltak. A mintavételek előtt a vizsgálatokat indokló feltételezett iránydiagnózis malignitás, patológiás nyirokcsomó-konglomerátum, valamint egy esetben hasfali sérv volt.

Eseteink közül kettőt emelnénk ki részletesebben.

Az elsô esetben egy 31 éves fiatal nó jelentkezett klinikánkon 2 hete tartó köldöktáji, változó intenzitású, de folyamatos görcsös fájdalommal. Fizikai vizsgálata során a köldöknek megfelelően cseresznye nagyságú, fájdalmas, mobilis rezisztenciát lehetett tapintani, amelyet köldöksérvként diagnosztizáltunk. Anamnéziséből kiemelendő, hogy kétszer volt császármetszése. Az ultrahangvizsgálat során igazolódott a köldöksérv: a köldöknek megfelelően egy 10-13 mm átmérőjü sérvtömlőt találtunk, mely duzzadt, echószegény zsírszövetet tartalmazott érágakkal (1. és 2. ábra). A sérvkapu 3-4 mm szélességû volt. Többszöri erőteljes provokáció hatására egy gázos bélkacs is a tömlőbe került, mely a provokáció megszűnte után a hasüregbe visszakerült. Így pár nappal az ultrahangvizsgálatot követően kis, incipiens kizáródott köldöksérv miatt hasfali rekonstrukció történt. A kimetszett sérvtömlő a tartalmával együtt szövettani feldolgozásra került, melynek eredménye endometriosist igazolt.

A második esetben egy 35 éves nőbeteg jelentkezett klinikánkon egy hónapja tartó hasi fájdalommal és diszkomfortérzéssel. Fizikális vizsgálata negatív volt, így az első képalkotó eljárásként hasi ultrahangvizsgálatot végeztünk. Anamnéziséből kiemelendő a császármetszés, illetve a 7 éve ismert és kezelt magasvérnyomás-betegség. A hasi ultrahangvizsgálat során a hasi szervek részéról kóros eltérést nem találtunk, de a hasfalban, a rectusizomban, a köldöktől jobbra egy 18 mm mélységi, 36 mm laterolateralis és $36 \mathrm{~mm}$ craniocaudalis kiterjedésü, fokozott vascularisatiót mutató echószegény eltérés látszott (3. ábra). Környezetében, az izom alatt nyirokcso-

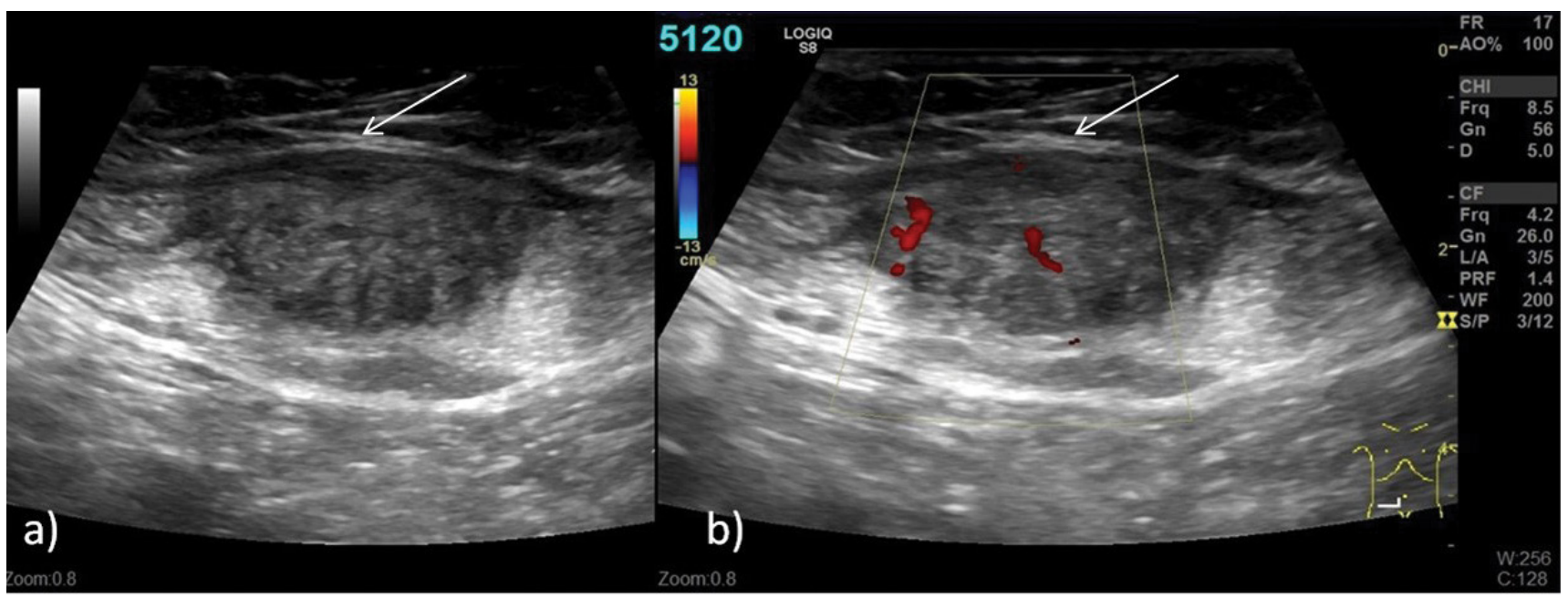

3. ábra $\quad$ A lineáris transzducerrel $(8,5 \mathrm{MHz})$ készített felvételeken jól látható a rectusizomban detektált echószegény, vascularisalt képlet (a, b; nyilak jelölik az elváltozást), melynek a szövettani diagnózisa endometrioma volt 


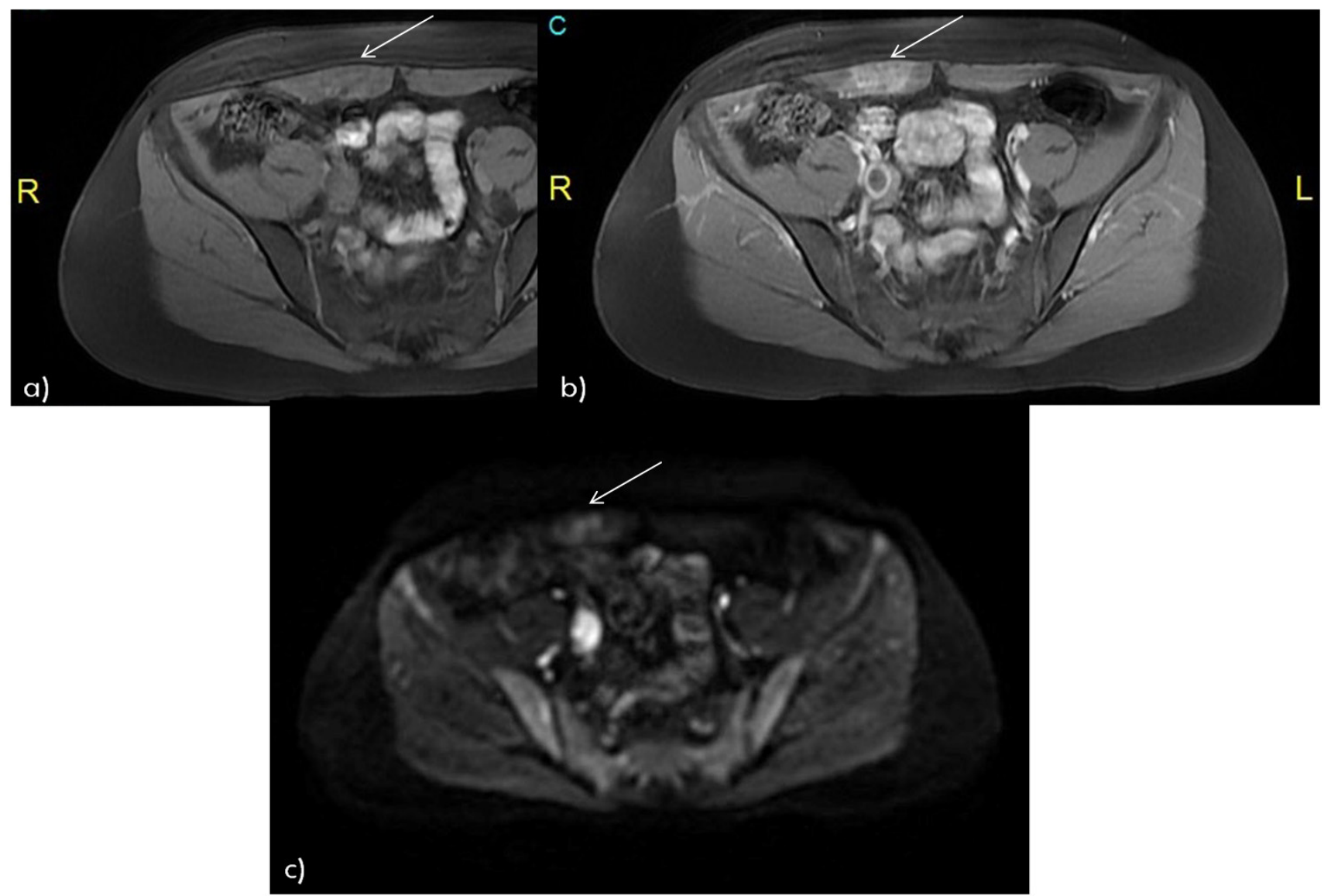
got viszont fokozottan halmozza b). A diffúziógátolt c) felvételen diffúziójában mérsékelten gátolt

mók is ábrázolódtak. Mivel az ultrahang a képlet dignitásáról érdemben nem tudott nyilatkozni, hasi és kismedencei MRI-vizsgálat is történt. Az MRI-vizsgálat során az ultrahangképen ábrázolt kiszélesedés is kimutatható volt, mely az izmot érdemben nem szélesítette, a kontrasztanyagot fokozottabban halmozta (4. ábra). Caudalisabban, a középvonaltól balra egy hasonló morfológiájú, fokozott halmozású, $20 \mathrm{~mm}$ átmérőjű terület is ábrázolódott, szintén a rectusizomban. Mivel a képletekkel kapcsolatban az MRI-vizsgálat sem tudott érdemben többet mondani, ultrahangvezérelt biopszia történt. A biopszia endometriosist igazolt. Később megtörtént a hasfali terimék mútéti eltávolítása is.

\section{Megbeszélés}

$\mathrm{Az}$ endometriosis jóindulatú, krónikus kórkép, melyet funkcionáló endometrium és stroma ectopiás, méhen kívüli elhelyezkedése, múködése okoz [7]. A rendelkezésre álló irodalom az endometrialis szövet méhen kívüli spontán megjelenését több elmélettel magyarázza, melyek közül a retrográd menstruációs teória a legelfogadottabb. E szerint a menstruációs vér és az endometrialis szövettörmelék a petevezetéken keresztül kerül, illetve tapad meg a hasüregben. A retrográd menstruáció során endometrialis epithelialis progenitorsejtek, illetve mesenchymalis őssejtszerû sejtek hatolnak be a hashártya rétegei közé ectopiás méhnyálkahártya-szigeteket létrehozva. A coelomahám endometrialis irányú differenciálódásával magyarázza a kórképet a metaplasztikus teória, mely elsősorban petefészek endometriosisa esetén feltételezhető. A harmadik pedig a vascularis és lymphaticus disszemináció elmélete, amely a nyirokrendszerben, illetve a medencén kívüli képletekben beágyazódott endometriumszövet jelenlétét magyarázza. Fóleg a Douglas-űr, illetve a sacrouterin szalagok endometriosisát okozhatja az egyedfejlődés során a Müller-cső sejtjeinek kóros migrációja és differenciálódása [8]. Az endometriosis kialakulásában szerepet játszhatnak még immunológiai, gyulladásos és genetikai tényezők is [9].

A hasfali endometriomák a leggyakrabban a császármetszések hegében fordulnak elő, amit a korábban említett implantációs teória magyaráz. Ezt az is alátámasztja, hogy a betegek ötödének a mútét idején nincs peritonealis endometriosisa, az endometrialis sejtek a mütét során sodródtak a hasfalba. Bár mintánk viszonylag kicsi, az általunk talált adatok ezzel összhangban vannak; 4 esetben történt MRI-vizsgálat, egy esetben a jobb ovariumrégióban lévő gócra derült fény, egy esetben még egy hasfali góc ábrázolódott. 
Az ectopiás endometrialis szövet hormondependens, ezzel magyarázható, hogy a megbetegedés többnyire reproduktív korú nőket érint. A stromalis sejtekben a normális szöveti sejtekhez viszonyítva fokozott az aromatázaktivitás, így jelentős az ösztrogéntermelés, továbbá ezen sejtek érzékenyebbek az ovarialis szteroidhormonokra, mint a normális endometriumszöveti sejtek. Az ösztrogén hatására a stromalis sejtek növekedési faktorokat állítanak elő, illetve szekretálnak, ami az ectopiás endometrium proliferációját és perzisztenciáját biztosítja. Progeszteronnal szemben azonban a sejtek kevésbé érzékenyek, így a proliferációs fázis hosszabb, mint a méhen belüli endometriumszövet esetén [10]. A szövet funkcionál, tehát részt vesz a ciklusos menstruációs vérzésben; ez makroszkóposan piros, kékes, esetleg barna, szoliter, 1-2 cm átmérőjű gócként vagy összefolyó elváltozásokként jelenik meg [8]. A ciklusos múködés következménye továbbá a hegszövetképződés, melynek következtében összenövések jöhetnek létre, ami tovább színesíti, súlyosbítja az endometriosis tüneteit. Az endometriosis a leggyakrabban a kismedencei szerveket érinti, de a hasüreg más területein is megjelenhet ectopiás endometriumszövet. A megbetegedés gyakran előfordul a nőgyógyászati szerveken kívül az urológiai, illetve a gastrointestinalis szervrendszerben is. Különösen súlyos tünetekkel járhat az endometriosis mélyen infiltráló formája, amely a peritoneumtól számított 5 mm-nél mélyebbre terjedő típust jelenti. Ezekben az esetekben az elváltozás elsősorban a kismedence hátsó részére lokalizálódik, de előfordulhat a kismedence elülső, illetve lateralis részén is; az érintett képlet lehet a plica vesicouterina, a húgyhólyag izomzata vagy szomatikus idegek [11].

A mélyen infiltráló endometriosis kimutatására a transvaginalis ultrahangvizsgálat jól alkalmazható. Az endometrioma szolid, echószegény nodularis képletként jelenhet meg a retrocervicalis régióban, az uterosacralis ligamentumon, a rectum vagy a húgyhólyag falában. Mivel az ultrahang gyorsabban, széles körben és költséghatékonyan hozzáférhető, a rutinképalkotásban megfelelö elsődlegesen választott képalkotó módszer; pontossága az MRI-vel összevethető, habár szenzitivitása és specificitása kissé az alatt marad. Mütéti tervezés esetén MRI végzése javasolt, amelynek során az összes, az ultrahang látóterén kívül eső góc is azonosítható.

Az MRI-vizsgálathoz közepesen telt hólyag szükséges, és bélrelaxáns adása javasolt, a vaginába vagy a rectumba gél felhelyezése opcionális. A mütéti tervezéshez intravénás kontrasztanyag adása nem szükséges, az endometrioma jól ábrázolódik a standard módon használt frekvenciákon [12]. A T2-súlyozott képeken a mélyen infiltráló endometrioma alacsony jelintenzitással ábrázolódik, a jelenlétére gyakran a ligamentum megvastagodása utal, Tl-súlyozott képeken jelintenzív [13].

Mivel az endometrioma megjelenése a ciklussal változik, felismerése kihívás elé állítja a képalkotással foglalkozó szakembereket. Az általunk elemzett mintában is két, jól elkülöníthető csoport van: postmenopausában lévő idősebb betegek malignus alapbetegséggel, valamint praemenopausában lévő fiatal betegek az anamnézisben hasfali mútéttel, mely - egy esetet kivéve, ahol lágyéksérvmütét szerepel - császármetszés volt.

A hasfali endometriosis klinikai megjelenése igen változatos, mérete vagy megjelenése nem ad differenciáldiagnosztikai támpontot, helye viszont segíthet a benignus kórkép felállításában. Általában mútéti hegben tapintható terimeként helyezkedhet el, mely az esetek 83,8\%ában fájdalmat okoz; a fájdalom lehet nem ciklikus vagy ciklikus jellegü. Az elváltozás mérete a menstruációs ciklussal növekedhet, melyhez dysmenorrhoeás panaszok is társulhatnak [14]. Császármetszés után kialakult endometriosis során a betegnek a szülés után hónapokkal vagy akár évekkel jelentkeznek panaszai. A császármetszés hegében lévő endometriosis kialakulása nincs összefüggésben azzal, hogy a beteg hány császármetszésen esett át élete folyamán [15]. A császármetszés hasfali hege körül kialakult endometriosis akut hasi kórképet is utánozhat [16]. Atípusos klinikai képnek tekinthető, amikor az endometriosis nem jár fájdalommal, illetve körülírt, tapintható elváltozással, s valamilyen képalkotó eljárás következtében véletlenül, mellékleletként fedezik fel. A diagnosztikai nehézségek miatt a hasfali endometriosis csak az esetek 20-50\%-ában kerül preoperatív felismerésre [17]. Malignus transzformációja igen ritka, kevés eset került közlésre az irodalomban. A hasfali endometriosis elsősorban endometriumcarcinomává, sarcomává és világos sejtes rákká differenciálódott. Prognózisa kifejezetten rossz [18].

A hasfalban tapintható vagy akár a mútét után kialakuló sérvben lévő kóros terimét először képalkotó eljárás segítségével azonosítjuk. Rutin hasi ultrahangvizsgálat során, ha csak az alacsony frekvenciájú konvex transzducert (4-9 MHz) használjuk, a hasfal nem látszik megfelelően, így a vizsgáló figyelmét elkerülheti a hasfalban elhelyezkedő kóros elváltozás. A hasfal részletes vizsgálatához a magasabb frekvenciájú, felszínes területeket jobb felbontásban ábrázoló lineáris transzducer (7-12 MHz) szükséges. Fontos, hogy ezt fiatal, bizonytalan hasi panaszokkal küzdő nőbetegnél minden esetben megtegyük. A hasfali endometriosis szolid inhomogén, összességében nézve echószegény, jól körülírt, vascularisalt képletként ábrázolódik, melyben a fibroticus komponens mennyiségétől függően echódús területek láthatók. A vérzéses területek a mestruációs ciklustól függően pedig echószegényként jelenhetnek meg a felvételeken. Lényeges, hogy mivel az endometriumcsomóban általában jó véráramlás van, a klasszikus Doppler-vizsgálat csak a tályog, valamint a sürü bennékü elváltozások esetében segíthet a karakterizálásban. A malignitás kizárása szempontjából nem ad több információt, mivel a malignus eltérések szintén élénk keringéssel rendelkeznek (5. ábra).

Az ultrahanggépek fejlődésével az eszköztár is növekedett; a strain elasztográfia elkülöníti egymástól a keményebb és puhább szöveteket, és mivel az endometrium- 


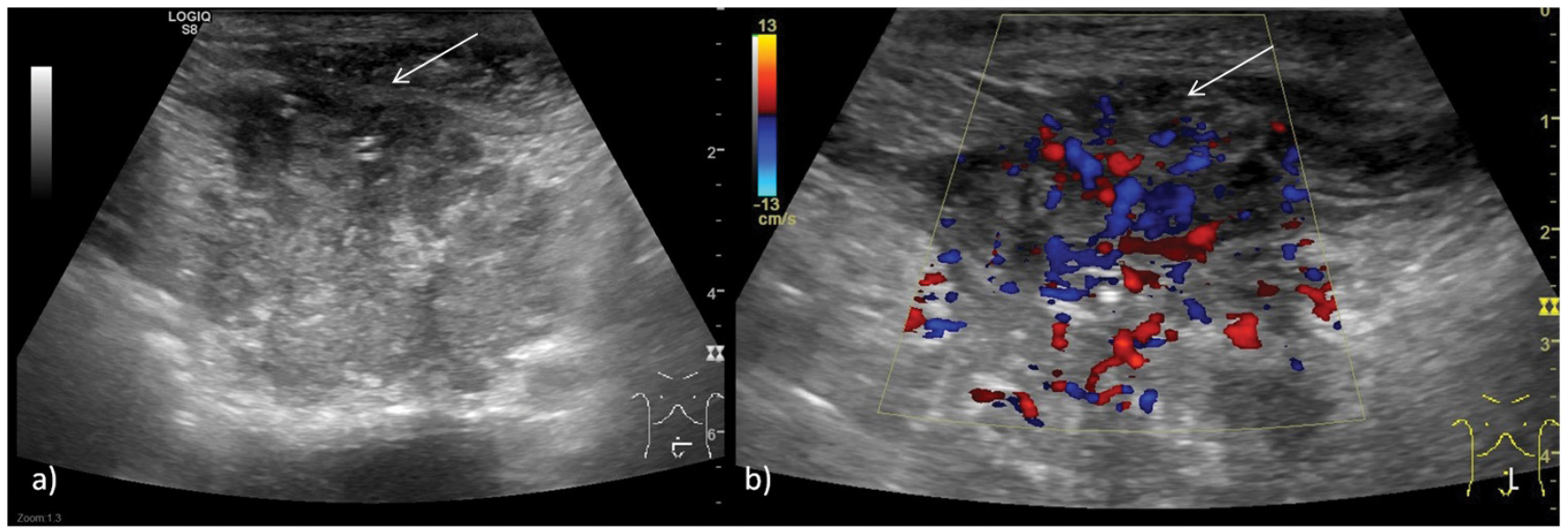

5. ábra

A 68 éves nőbeteg colorectalis carcinoma hasfali áttéte (nyillal jelölt terület), mely megjelenését tekintve körülírt, jól vascularisalt, inhomogén képlet, endometriomához hasonló

csomó a környezeténél keményebb szövetként ábrázolódik, mely jól elhatárolódik az azt körülvevő lágyrészektől, segíthet a mütét pontos megtervezésében -differenciáldiagnosztikai hasznossága azonban vitatható. A háromdimenziós ultrahangkép-alkotás hasfali endometriosis esetén, fóként ha a szélek egyenetlenek, spikuláltak, hasznos a mútét előtti térfogat, a mélységi terjedés becslésében, ezzel elősegítve, hogy az endometrioma az ép részben legyen eltávolítva [19]. Mivel erezettsége fokozott, a kontrasztanyag adása az ultrahangvizsgálat során nem vezet pluszinformációhoz. A minimálinvazív eljárások terjedésével egy új terápiás lehetőség az ultrahangvezérelt ablatio, mely napjainkban kezd teret hódítani $[20,21]$.

A CT-t önmagában nem érdemes használni a hasfali endometriosis kizárására, megerősítésére vagy kivizsgálására a szegényes képi felbontása és a nagy sugárdózis miatt. Specificitása és szenzitivitása még kontrasztanyag adásával is jóval az ultrahang- és az MRI-vizsgálaté alatt marad. A hasfali endometriosis megjelenése a CT-képeken atípusos, szolid lágyrészként ábrázolódik. Támpontot esetlegesen az elhelyezkedése adhat, mely régebbi mütéti terület, a heg környezetében van. A natív és intravénás kontrasztanyag beadását követő hasi és kismedencei CT-vizsgálat endometrioma esetén a diagnózis felállításában nem segít, az endometriumcsomó a malignus eltérésekhez hasonlóan fokozott halmozást mutat, a környezetében levő struktúráktól jól elkülönülő terimeként ábrázolódik (6. ábra). Mivel az endometriosis elsősorban fiatal, reproduktív korban lévő nőket érintő betegség, a felesleges sugárdózist az észszerüen elérhető legalacsonyabb sugárzási szint elve (ALARA-elv) alapján mindenképpen kerülni kell [22].

A differenciáldiagnosztika szempontjából az MRI lehet segítségünkre. Az MRI lehetővé teszi a mirigyes és a fibroticus területek elkülönítését az endometriumcsomón belül. Mind a T1-, mind a T2-súlyozott MRI-kép irányadó az endometriomából történő vérzés feltérképezéséhez, T2-súlyozott képen azonban kisebb jelintenzi- tással ábrázolódik a fibroticus komponensek miatt. A hemosziderindepozitumok, melyek a krónikus vérzés jelei, T1-, T2-módban, illetve T2* -szekvencia során is alacsony jelintenzitásúak lesznek. Az endometrioma a kontrasztanyagot fokozottan halmozza, és mivel sejtdús, a vízmolekulák Brown-mozgása korlátozott, tehát körülírt, diffúziójában mérsékelten gátolt képletként jelenik meg. A vizsgálat során képet kaphatunk a hasüregben lévő, ultrahangvizsgálat során nehezen vagy nem azonosítható ectopiás endometriumszövetről is (4. ábra) [15].

$\mathrm{Az}$ átlagos ectopiás endometriumgóc kiterjedése 2,5 $\mathrm{cm}$, mely a mi adatainkkal is összhangban van [6]. A pontos diagnózishoz szükséges következő lépés valamely képalkotó, általában ultrahang által vezérelt vékonytü-aspiráció. Mivel az aspirációval csak a sejtek atípiájáról, illetve esetleges malignitásról lehet nyilatkozni, a diagnózishoz szükséges lehet a mútét és ennek során az eltávolított szövet teljes szövettani vizsgálata. Ez hangsúlyos lépés, ha malignitás merült fel, és ilyen esetben meg kell állapítani, hogy az elváltozás épben lett-e eltávolítva.

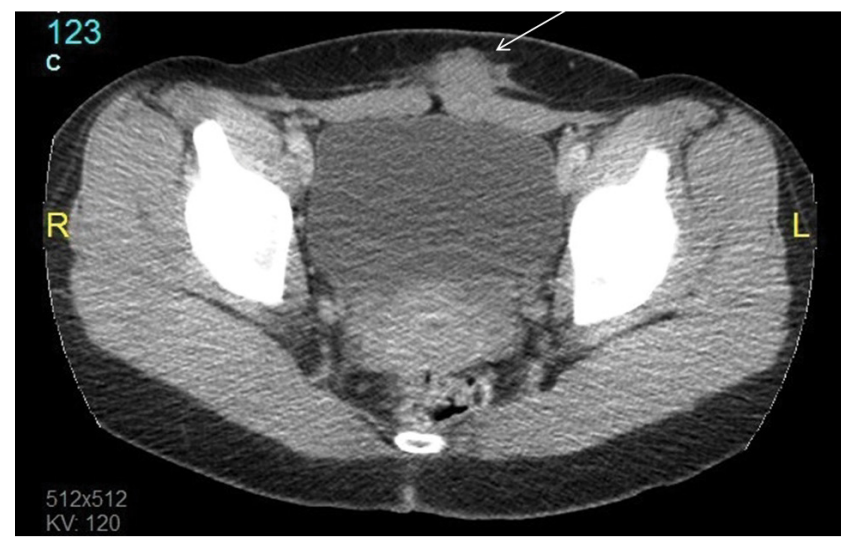

6. ábra A 35 éves nőbetegnél hasi és kismedencei CT-vizsgálat során észleltük a hasfali terimét. A hasfal bal oldalán található a rectusizom ventralis felszínén lévő, kontrasztanyagot mérsékelten halmozó eltérés (nyíl). Az ultrahangvezérelt mintavétel endometriosist igazolt 


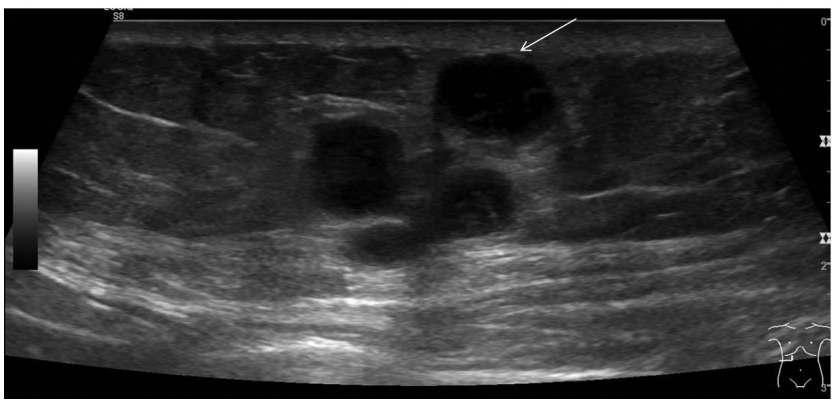

7. ábra

A 61 éves beteg primer ovariumcarcinoma-metasztázisai, ritka előfordulási helyen, a hasfali subcutis rétegeiben (nyíl)

Életkor szerinti előfordulás alapján differenciáldiagnosztikai szempontból a lágyrész-tumorok merülhetnek fel, de ezek a hasfalban extrém ritkán fordulnak elö, ugyanis az ebben az életkorban előforduló liposarcoma vagy malignus fibrosus histiocytoma leggyakoribb elöfordulási helye a végtag, valamint a retroperitoneum. Így a képlet elhelyezkedése is jó differenciáldiagnosztikai szempont lehet [23]. Kiemelendő, hogy a hasfali endometriosis képét igen könnyen össze lehet téveszteni a jóindulatú lágyrész-tumorral, a desmoiddal, mely kiterjedt fibroticus komponense révén CT-vizsgálatok során könynyen utánozhat krónikus endometriomát, illetve klinikuma szempontjából is összetéveszthető, ugyanis a leggyakrabban ugyanúgy a fiatalokat érinti: átlagosan 25-35 év között jelenik meg [24].

Lokalizáció szerint differenciáldiagnosztikai szempontból az izmokban lévő metasztázis jön szóba, ez a leggyakrabban tüdőrák esetében fordul elö, de gyakori lehet ovariumcarcinomában és gastrointestinalis daganatokban is (7. ábra) [25]. A metasztázis elsősorban az iliopsoas-, paravertebralis, glutealis izmokban és a láb izmaiban jelenik meg, a hasfal izmaiban előfordulása viszonylag ritka. Egy betegség emelendő ki, a melanoma malignum, melynek korspecifikus incidenciája ebben az életkorban kezd növekedni. Ritkán adhat hasfalon subcutan vagy izomban elhelyezkedő metasztázist, mellyel viszont számolni kell [26, 27].

Tályog esetében általában gáz-folyadék nívót találunk, a haematomát, granulomát vagy seromát általában egy nemrég történt beavatkozás vagy trauma előzi meg. Ezekben az esetekben a korrekt anamnézis és klinikum figyelembevétele elengedhetetlen a megfelelő diagnózis felállításához, illetve a differenciáldiagnosztikai hibák elkerüléséhez (8. ábra).

\section{Következtetés}

$\mathrm{Az}$ endometriosis egyre gyakrabban előforduló megbetegedés. Előfordulása összefügg a császármetszések és a transabdominalisan végzett beavatkozások növekedésének számával, így egyre több atípusos megjelenésre kell számítanunk.

Ultrahangvizsgálat során fiatal nőbetegben talált hasfali, echószegény terime esetében, amennyiben a malignitás a kórtörténetben nem szerepel, viszont császármetszés igen, hasfali endometriosist célszerú a legvalószínúbb diagnózisnak tartani, ezzel megkímélve a beteget az

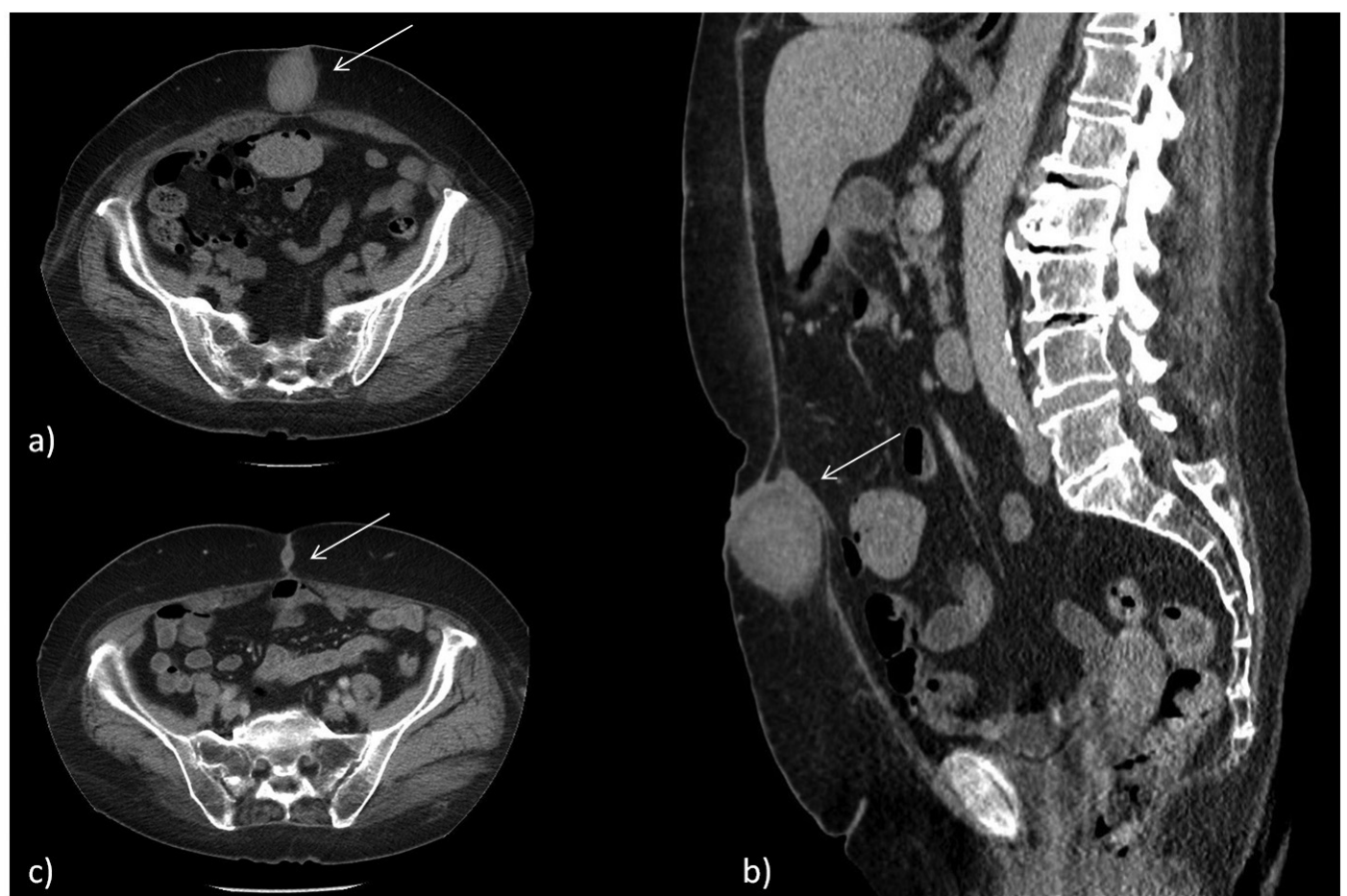

8. ábra

A 76 éves nőbeteg CT-leletén hasfali, periumbilicalis elhelyezkedésû́ terime látható ( $a$, $b$; nyíl). Morfológiája nagyon hasonló az endometrioma CTmegjelenéséhez (6. ábra). A páciensnél tályogrendszer igazolódott, mely drenálásra került; a beavatkozás után készült kontroll-CT-vizsgálat során az eltérés mérete már jelentős csökkenést mutatott $(c$; nyíl) 
esetleges malignitás miatti pszichés stressztől. A szövettani feldolgozás nem kerülhető el, egyéb képalkotó eljárások a mintavétel előtt nem szükségesek; MRI-vizsgálat a mútéti tervezés, intraabdominalisan elhelyezkedő endometriomák feltérképezése során válhat szükségessé.

Anyagi támogatás: A közlemény megírása anyagi támogatásban nem részesült.

Szerzői munkamegosztás: Cs. Cs.: A vizsgálati szempontok kidolgozása a képalkotás szemszögéből, szakirodalmi másodelemzés, adatgyüjtés, a kézirat szövegezése. P. N.: A vizsgálati szempontok kidolgozása klinikusi oldalról, szakirodalmi másodelemzés, a kézirat szövegezése. Sz. E., K. G.: Adatgyüjtés, szakirodalmi másodelemzés. P. A., F. Zs.: A kézirat szövegezése. A cikk végleges változatát valamennyi szerző elolvasta és jóváhagyta.

Érdekeltségek: A szerzőknek nincsenek érdekeltségeik.

\section{Irodalom}

[1] Mehedintu C, Plotogea MN, Ionescu S, et al. Endometriosis still a challenge. J Med Life 2014; 7: 349-357.

[2] Eisenberg VH, Weil C, Chodick G, et al. Epidemiology of endometriosis: a large population-based database study from a healthcare provider with 2 million members. BJOG 2018; 125: 55-62.

[3] Parasar P, Ozcan P, Terry KL. Endometriosis: epidemiology, diagnosis and clinical management. Curr Obstet Gynecol Rep. 2017; 6: 34-41.

[4] Sinha R, Kumar M, Matah M. Abdominal scar endometriosis after Caesarean section: a rare entity. Australas Med J. 2011; 4: 60-62.

[5] Mistrangelo M, Gilbo N, Cassoni P, et al. Surgical scar endometriosis. Surg Today 2014; 44: 767-772.

[6] Vellido-Cotelo R, Muñoz-González JL, Oliver-Pérez MR, et al Endometriosis node in gynaecologic scars: a study of 17 patients and the diagnostic considerations in clinical experience in tertiary care center. BMC Women's Health 2015; 15: 13.

[7] Malutan AM, Simon I, Ciortea R, et al. Surgical scar endometriosis: a series of 14 patients and brief review of literature. Clujul Med. 2017; 90: 411-415.

[8] Kumar V, Abbas AK, Aster JC. Robbins Basic Pathology. [Robbins: A patológia alapjai.] Medicina Könyvkiadó, Budapest, 2014; pp. 819-820.

[9] Lampé L. Endometriosis. [Endometriosis.] Orv Hetil. 2009; 150: 245-250. [Hungarian]

[10] Sourial S, Tempest N, Hapangama DK. Theories on the pathogenesis of endometriosis. Int J Reprod Med. 2014; 2014: 79515

[11] Lukovich P, Csibi N, Brubel R, et al. Prospective study to determine the diagnostic sensitivity of sigmoidoscopy in bowel endometriosis. [Prospektív vizsgálat a sigmoideoscopia diagnosztikai érzékenységének meghatározására vastagbelet infiltráló endometriosisban.] Orv. Hetil. 2017; 158: 264-269. [Hungarian]

[12] Bazot M, Daraï E. Diagnosis of deep endometriosis: clinical examination, ultrasonography, magnetic resonance imaging, and other techniques. Fertil Steril. 2017; 108: 886-894.

[13] Alborzi S, Rasekhi A, Shomali Z, et al. Diagnostic accuracy of magnetic resonance imaging, transvaginal, and transrectal ultrasonography in deep infiltrating endometriosis. Medicine (Baltimore) 2018; 97: e9536.

[14] Lopez-Soto A, Sanchez-Zapata MI, Martinez-Cendan JP, et al. Cutaneous endometriosis: presentation of 33 cases and literature review. Eur J Obstet Gynecol Reprod Biol. 2018; 221; 58-63.

[15] Kocher M, Hardie A, Schaefer A, et al. Cesarean-section scar endometrioma: a case report and review of the literature. J Radiol Case Rep. 2017; 11: 16-26.

[16] Gajjar KB, Mahendru AA, Khaled MA. Caesarean scar endometriosis presenting as an acute abdomen: a case report and review of literature. Arch Gynecol Obstet. 2008; 277: 167-169.

[17] Grigore M, Socolov D, Pavaleanu I, et al. Abdominal wall endometriosis: an update in clinical, imagistic features, and management options. Med Ultrason. 2017; 19: 430-437.

[18] Bats AS, Zafrani Y, Pautier P, et al. Malignant transformation of abdominal wall endometriosis to clear cell carcinoma: case report and review of the literature. Fertil Steril. 2018; 90: 1197.e131197.el6.

[19] Picard A, Varlet MN, Guillibert F, et al. Three-dimensional sonographic diagnosis of abdominal wall endometriosis: a useful tool? Fertil Steril. 2011; 95: 289.el-289.e4.

[20] Luo S, Zhang C, Huang JP, et al. Ultrasound-guided high-intensity focused ultrasound treatment for abdominal wall endometriosis: a retrospective study. BJOG 2017; 124(Suppl 3): 59-63.

[21] Lee JS, Kim YJ, Hong GY, et al. Abdominal wall endometriosis treatment by ultrasound-guided high-intensity focused ultrasound ablation: a case report. Gynecol Endocrinol. 2019; 35: 109-111.

[22] Ecker AM, Donnellan NM, Shepherd JP, et al. Abdominal wall endometriosis: 12 years of experience at a large academic institution. Am J Obstet. 2014; 211: 363.el-363.e5.

[23] Karki B, Xu YK, Wu YK, et al. Primary malignant fibrous histiocytoma of the abdominal cavity: CT findings and pathological correlation. World J Radiol. 2012; 4: 151-158.

[24] Dinauer PA, Brixey CJ, Moncur JT, et al. Pathologic and MR imaging features of benign fibrous soft-tissue tumors in adults. Radiographics 2017; 27: 173-187.

[25] Surov A, Hainz M, Holzhausen HJ, et al. Skeletal muscle metastases: primary tumours, prevalence, and radiological features. Eur Radiol. 2010; 20: 649-658.

[26] Ali Z, Yousaf N, Larkin J. Melanoma epidemiology, biology and prognosis. EJC Suppl. 2013; 11: 81-91.

[27] Trout AT, Rabinowitz RS, Platt JF, et al. Melanoma metastases in the abdomen and pelvis: frequency and patterns of spread. World J Radiol. 2013; 5: 25-32.

(Fejes Zsuzsanna dr., Szeged, Semmelweis u. 6., 6725 e-mail: dr.fejes.zsuzsanna@gmail.com)

A cikk a Creative Commons Attribution 4.0 International License (https://creativecommons.org/licenses/by/4.0/) feltételei szerint publikált Open Access közlemény, melynek szellemében a cikk bármilyen médiumban szabadon felhasználható, megosztható és újraközölhető, feltéve, hogy az eredeti szerző és a közlés helye, illetve a CC License linkje és az esetlegesen végrehajtott módosítások feltüntetésre kerülnek. (SID_1) 